\title{
Peramalan Penjualan Kendaraan Mobil Segmen B2B dengan Metode Regresi Linear Berganda, Jaringan Saraf Tiruan, dan Jaringan Saraf Tiruan- Algoritma Genetika
}

\author{
Muhammad Agung Nugraha $^{a, *}$, Farizal $^{b}$, Djoko Sihono Gabriel $^{c}$

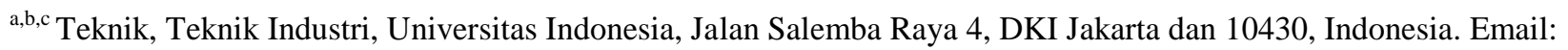 \\ agunugraha@gmail.com
}

\section{A B S T R A C T}

This study aims to create an effective forecasting model in predicting sales of car products in the B2B segment (Business to Business) to obtain estimates of product sales in the future. This research uses multiple linear regression and artificial neural networks that are optimized by genetic algorithms. Forecasting factors for car sales are generally issued by total national car sales, the Consumer Price Index, the Consumer Confidence Index, the Inflation Rate, Gross Domestic Product (GDP), and Fuel Oil Price. The author has also gotten the factors that play a role in the sale of $B 2 B$ segment by diverting the survey to 106 DMU (Decision Making Unit) who decide to purchase cars in their company. Then we evaluate the results of the questionnaire in training data and simulations on the Artificial Neural Network. Optimized Artificial Neural Networks with Genetic Algorithms can improve B2B segment car sales' accuracy when comparing error values in the ordinary Artificial Neural Network and Multiple Linear Regression.

Keywords: Artificial Neural Networks, Automotive Industry, Forecasting, Genetic Algorithms, Multiple Linear Regression.

\section{A B S T R A K}

Penelitian ini bertujuan untuk membuat model peramalan yang efektif dalam meramalkan penjualan produk mobil dalam segmen B2B (Business to Business) agar didapatkan estimasi penjualan produk di masa mendatang. Peneilitian ini menggunakan regresi linear berganda dan jaringan saraf tiruan yang dioptimasi dengan algoritma genetika. Faktor peramalan penjualan mobil pada umumnya meliputi total penjualan mobil secara nasional, Indeks Harga konsumen, Indeks Kepercayaan Konsumen, Laju Inflasi, Produk Domestik Bruto (GDP), dan Harga Bahan Bakar Minyak (BBM). Penulis juga telah mendapatkan faktor yang berpengaruh dalam penjualan segmen B2B dengan menyebarkan survei kuesioner kepada 106 orang DMU (Decision Making Unit) yang memiliki keputusan dalam pembelanjaan mobil diperusahaan mereka. Kemudian hasil scoring dari kuesioner tersebut kami bobotkan

* Corresponding author.

Alamat e-mail: agunugraha@gmail.com 
pada data training dan simulasi pada Jaringan Saraf Tiruan. Hasil penelitian ini menunjukkan bahwa Jaringan Syaraf Tiruan yang dioptimasi dengan Algoritma Genetika dapat meningkatkan akurasi peramalan penjualan mobil segmen B2B, jika dibandingkan nilai error pada Jaringan Saraf Tiruan biasa dan Regresi Linear Berganda.

Kata Kunci: Algoritma Genetika, Industri Otomotif, Jaringan Saraf Tiruan, Peramalan, Regresi Linier Berganda. Diserahkan: 11-10-2020; Diterima: 23-12-2020; Doi: https://doi.org/10.29303/emj.v3i2.80

\section{Pendahuluan}

Industri otomotif Indonesia telah menjadi sebuah pilar penting dalam sektor manufaktur negara ini karena banyak perusahaan mobil yang terkenal di dunia membuka (kembali) pabrik-pabrik manufaktur mobil atau meningkatkan kapasitas produksinya di Indonesia, negara dengan ekonomi terbesar di Asia Tenggara. Indonesia memiliki industri manufaktur mobil terbesar kedua di Asia Tenggara dan di wilayah ASEAN (setelah Thailand yang menguasai sekitar 50 persen dari produksi mobil di wilayah ASEAN).

Penjualan kendaraan roda empat di Indonesia mulai menunjukkan tren positif selama tahun 2018 . Di tengah stagnansi ekonomi global, penjualan mobil mampu menembus angka psikologis baru sebanyak 1,15 juta unit, setelah tiga tahun bertengger di kisaran 1 jutaan unit. Berdasarkan data Gabungan Industri Kendaraan Bermotor Indonesia (Gaikindo), penjualan mobil sepanjang 2018 tumbuh 6,86\% dibandingkan tahun sebelumnya. Jumlah penjualannya melebihi target yang dicanangkan sebesar 1,1 juta unit. Puncak penjualan mobil Indonesia terjadi pada 2013 lalu sebanyak 1,23 juta unit. Setelah itu, angka penjualannya terus merosot.

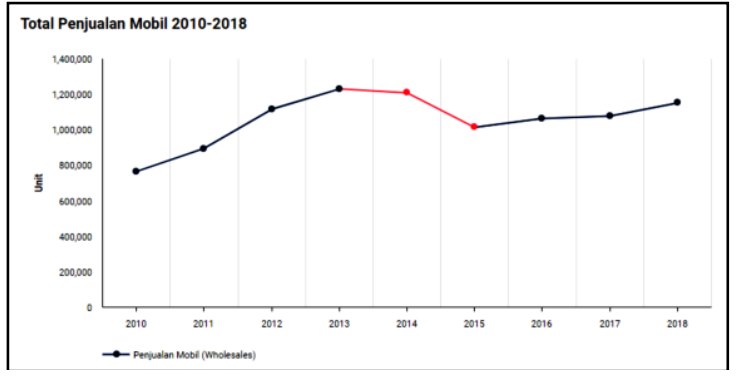

Gambar 1 - Total Penjualan Mobil di Indonesia (Wholesales) (Sumber: GAIKINDO)

Selain konsumen individual, penjualan kendaraan mobil di Indonesia juga sangat ditopang oleh penjualan dalam volume besar ke konsumen dari segmen perusahaan. Konsumen jenis ini biasanya melakukan pembelian kendaraan baru dalam jumlah besar untuk replacement (penggantian) kendaraan yang lama, maupun untuk menambah jumlah armada. Segmen konsumen ini biasanya disebut dengan istilah fleet customer (B2B) dan menjadi incaran banyak brand otomotif karena volume pembeliannya yang besar. Menurut (Brax \& Visintin, 2017). Pelanggan B2B menuntut nilai lebih dari pemasok mereka. Oleh karenanya semakin banyak pemasok menawarkan layanan bernilai tambah untuk meningkatkan kinerja produk inti mereka dalam sistem nilai pelanggan. Produsen/ manufacturer mengorganisir diri untuk memberikan layanan dan 'penawaran solusi terintegrasi yang menggabungkan produk dan layanan fisik.

Berdasarkan pada perbandingan penjualan Mobil tahun 2017 dan 2018 (whole sales) terjadi peningkatan penjualan dari 1.079 .886 unit tahun 2017 menjadi 1.151.413 unit pada tahun 2018. Dari data penjualan tersebut pada tahun 2018, penulis mengolah data market fleet customer (B2B) dan didapatkan bahwa kontribusi pasar B2B di Indonesia yaitu sebesar 13,37 \% atau sebanyak 153.987 unit pertahun. Hal ini menjadi menarik untuk diteliti lebih lanjut relevansi antara pengaruh variabel pada penjualan kendaraan secara umum (wholesales) apakah sama dengan penjualan pada pasar segmen (B2B), kemudian mencari variabel lainnya dari literatur maupun survey kuesioner untuk mencari lebih lanjut variabel dependen yang mempengaruhi permintaan kendaraan pada segmen B2B.

Penelitian ini bertujuan untuk mengungkapkan faktor signifikan, yang mempengaruhi penjualan mobil dan memperkirakan penjualan mobil di Indonesia untuk segmen perusahaan (B2B) dengan membandingkan akurasi peramalan pada Regresi Linear Berganda dan Jaringan Syaraf Tiruan (JST) yang dioptimalkan menggunakan Algoritma Genetika.

\section{Metode}

\subsection{Peramalan Penjualan}

Peramalan penjualan yang akurat memainkan peran penting dalam persaingan pasar mobil, dan produsen mobil perlu memperkirakan penjualan untuk mencapai tujuan yang diinginkan. Keakuratan prediksi secara langsung mempengaruhi perusahaan dalam menilai pola permintaan pasar, mengidentifikasi kekuatan kompetitif dan menentukan strategi pengembangan produk (Gao, et 
al., 2018). Sejumlah asumsi mengenai perilaku pelanggan dan pesaing serta lingkungan pasar, dan oleh karena itu, keandalannya bergantung pada sejumlah parameter yang tidak pasti (Chouksey, et al, 2018). Ada banyak faktor yang mempengaruhi penjualan mobil, dan ada korelasi yang melekat di antara mereka.

Dalam studi ini, untuk menentukan faktor-faktor yang digunakan dalam meramalkan penjualan mobil, penulis memeriksa faktor-faktor yang digunakan dalam studi literatur. Kemudian, dengan menambahkan faktor-faktor yang spesifik untuk segmen perusahaan (B2B), berdasarkan studi literatur dan kuesioner sebagai faktor-faktor yang akan digunakan dalam penelitian ini. Faktor-faktor ini adalah jumlah penjualan wholesales, PDB, Jumlah populasi di Indonesia, Laju inflasi dan Indeks Harga Konsumen. Selain itu didapatkan bahwa pengaruh penjualan segmen perusahaan (B2B) dipengaruhi oleh variabel 4P (Price, Promotion, Place and Product).

\subsection{Penentuan Faktor}

\subsubsection{Faktor penjualan mobil secara umum}

Penentuan faktor-faktor yang mempengaruhi jumlah permintaan/ penjualan suatu barang juga berlandaskan studi literatur terhadap penelitianpenelitian terdahulu dan pendapat ekspert. Hasil studi literatur jurnal terkait faktor-faktor yang mempengaruhi jumlah permintaan kendaraan mobil secara umum, didapatkan 6 faktor tertinggi yaitu :

Tabel 1 - Faktor Independen

\begin{tabular}{cl}
\hline No & \multicolumn{1}{c}{ Faktor } \\
\hline 1 & Total Whole Sales Market (per-bulan) \\
2 & GDP Growth \\
3 & Laju Inflasi (\%) \\
4 & Customer Satisfaction Index \\
5 & Consumer Confidence Index (CCI) \\
6 & Harga Bahan Bakar (Gasoline) \\
\hline
\end{tabular}

Berdasarkan hasil studi literatur terdahulu didapatkan faktor-faktor yang berpengaruh pada penjualan mobil secara umum dilihat dari 20 jurnal terdahulu yaitu Total Whole Sales market, GDP, Laju inflasi, Indeks kepuasan pelanggan, Indeks kepercayaan konsumen dan Harga bahan bakar. Kemudian faktor tersebut kami jadikan sebagai variabel independen untuk diteliti pengaruhnya terhadap actual penjualan secara B2B.

\subsubsection{Faktor penjualan mobil secara B2B}

Dalam penentuan faktor yang menjadi variabel B2B bebas (independent) dalam penelitian ini didasarkan pada jurnal terdahulu yaitu The Impact of $B 2 B$ Buying Behavior on Customer Satisfaction within SHAHAB KHODRO Company bahwa Dari aspek perusahaan, keputusan pembelian dapat dipengaruhi oleh pemasok melalui seperangkat alat pemasaran, yang disebut 4P (Jennie, et al, 2005). Dalam penelitian ini peneliti melakukan survei dengan memberikan kuesioner menggunakan kriteria targetnya pada 106 orang DMU (Decision Making Unit) pada setiap perusahaan yang diantaranya memiliki posisi atau jabatan yaitu General Affair, Purchasing, Manager, User, dan Owner.

Berdasarkan data terdapat 11 indikator dari variabel B2B yang telah dihimpun dari 106 responden dan kemudian menggunakan teknik scoring untuk mendapatkan nilai kepuasan pelanggan terhadap 4P dari Suzuki. Adapun bobot yang akan digunakan dalam variabel B2B ini sebagai berikut :

Tabel 2 - Keterangan Tabel Pembobotan

\begin{tabular}{llcc}
\hline Tabel 1 & After Sales Service & 493 & $\mathbf{0 , 9 1 9 0 9}$ \\
\hline Tabel 2 & $\begin{array}{l}\text { Technical } \\
\text { Performance }\end{array}$ & 491 & $\mathbf{0 , 9 1 5 3 6 2}$ \\
\hline Tabel 3 & Product Knowledge & 488 & $\mathbf{0 , 9 0 9 7 6 9}$ \\
\hline Tabel 4 & Feature & 491 & $\mathbf{0 , 9 1 5 3 6 2}$ \\
\hline Tabel 5 & Easy to Service & 484 & $\mathbf{0 , 9 0 2 3 1 2}$ \\
\hline Tabel 6 & Price Fit & 485 & $\mathbf{0 , 9 0 4 1 7 6}$ \\
\hline Tabel 7 & Communication & 486 & $\mathbf{0 , 9 0 6 0 4}$ \\
\hline Tabel 8 & Marketing Activity & 488 & $\mathbf{0 , 9 0 9 7 6 9}$ \\
\hline Tabel 9 & Relationship & 490 & $\mathbf{0 , 9 1 3 4 9 7}$ \\
\hline Tabel 10 & $\begin{array}{l}\text { Geographical } \\
\text { Distance }\end{array}$ & 484 & $\mathbf{0 , 9 0 2 3 1 2}$ \\
\hline Tabel 11 & Time Delivery & 484 & $\mathbf{0 , 9 0 2 3 1 2}$ \\
\hline & Total & $\mathbf{5 3 6 4}$ & $\mathbf{1 0}$ \\
\hline
\end{tabular}

Merujuk pada pembobotan yang dilakukan dengan membagi besaran skor dengan total seluruh skor, maka didapatkan bahwa pelayanan purna jual mendominasi dari kepuasan pelanggan, disusul 
variabel berikutnya yaitu performansi teknis kendaraan dan fitur yang dimiliki oleh kendaraan.

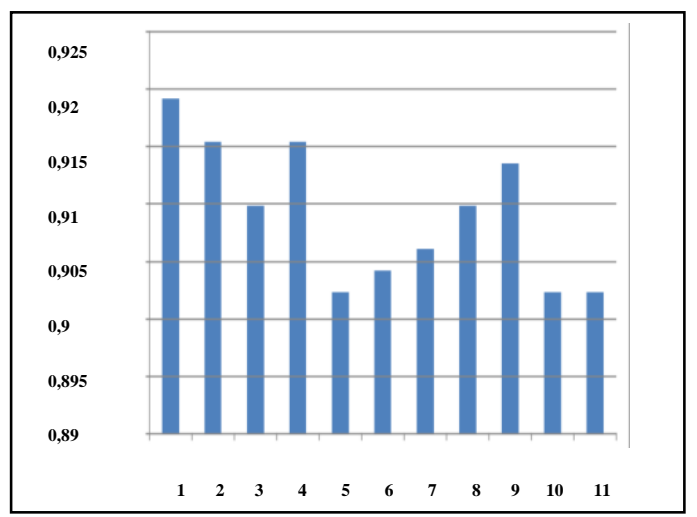

Grafik 2 - Grafik Pembobotan Variabel B2B

Sementara itu variabel yang diantaranya memiliki nilai bobot terendah yaitu apabila keterkaitan kepuasan pelanggan pada $4 \mathrm{P}$ yang dilakukan oleh penjual mengenai kemudahan pelayanan, jarak geografis atau akses menuju dealer dan juga waktu pengiriman.

\subsection{Regresi Linear Berganda}

Regresi pertama kali dikemukakan oleh Francis Gilton dalam artikelnya "Family Likeness in Stature" di tahun 1886. Studi Gilton menghasilkan hukum regresi universal tentang tingginya anggota masyarakat. Regresi berganda merupakan hubungan fungsional antara dua atau lebih variabel independent $(X)$ terhadap satu variabel dependent $(Y)$, sehingga dari hubungan tersebut nilai variabel dependent $(Y)$ dapat diprediksi pada nilai- nilai tertentu dari variabel-variabel independent $(X)$ (Draper dan Smith, 1992).

Data terdiri dari $n$ set pengamatan $\left\{X_{1}, X_{2}, X_{3}, \ldots\right.$, $\left.X_{p}, y\right\}$, yang mewakili sampel acak dari populasi yang lebih besar. Diasumsikan bahwa pengamatan ini memenuhi hubungan linier,

$$
Y=\alpha_{0}+\alpha_{1} X_{1}+\alpha_{2} X_{2}+\alpha_{3} X_{3}+\ldots \ldots+\alpha_{p} X_{p}+\varepsilon
$$

Koefisien $\alpha$ adalah parameter yang tidak diketahui, dan $\varepsilon$ adalah istilah kesalahan acak. Dengan model linier, ini berarti bahwa model linear dalam parameter model kuadratik. Model linier cukup paradoks karena $X$ dan $X^{2}$ hanyalah versi dari $X_{1}, X_{2}$, dan $X_{3}$.

$$
Y=\alpha_{0}+\alpha_{1} X_{1}+\alpha_{2} X_{2}+\alpha_{3} X_{3}+\varepsilon
$$

Penting untuk menyadari bahwa ini, atau model statistik apa pun tidak dipandang sebagai representasi realitas yang sebenarnya, melainkan tujuannya adalah agar model tersebut menjadi representasi realitas yang bermanfaat. Sebuah model dapat digunakan untuk mengeksplorasi hubungan antar beberapa variabel dan membuat perkiraan yang akurat berdasarkan pada hubungan tersebut meskipun itu bukan "kebenaran".

\subsection{Jaringan Saraf Tiruan}

Prinsip jaringan saraf tiruan (JST) ditentukan oleh tiga elemen dasar model saraf, yaitu:

1. Satu set dari sinapsis, atau penghubung yang masing-masing digolongkan oleh bobot atau kekuatannya.

2. Sebuah penambah untuk menjumlahkan sinyalsinyal input. Ditimbang dari kekuatan sinaptik masing-masing neuron.

3. Sebuah fungsi aktivasi untuk membatasi amplitudo output dari neuron. Fungsi ini bertujuan membatasi jarak amplitudo yang diperbolehkan oleh sinyal output menjadi sebuah angka yang terbatas.

Prinsip jaringan saraf tiruan secara sederhana digambarkan sebagai berikut.

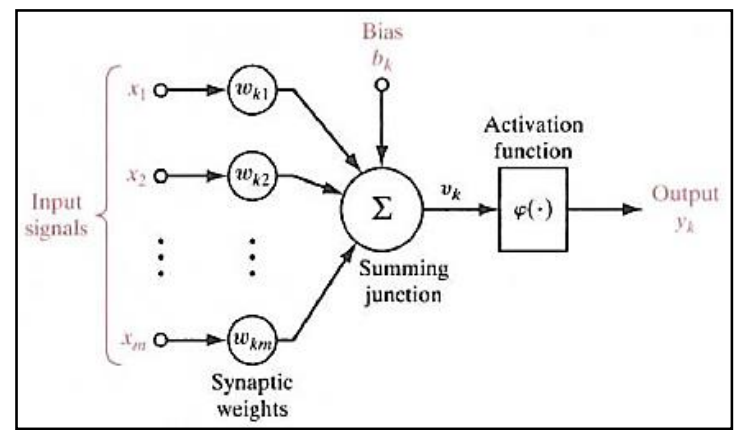

Gambar 3 - Prinsip Dasar Jaringan Saraf Tiruan (JST)

Pada Gambar 3, $Y$ menerima masukan dari neuron $x_{1}, x_{2}$, dan $x_{3}$, dengan bobot hubungan masing-masing adalah $w_{1}, w_{2}$, dan $w_{3}$. Ketiga impuls neuron yang ada dijumlahkan menjadi:

$N e t=x_{1} w_{1}+x_{2} w_{2}+x_{3} w_{3}$

Besarnya impuls yang diterima oleh $Y$ mengikuti fungsi aktivasi $y=f($ net $)$. Apabila nilai fungsi aktivasi cukup kuat, maka sinyal akan diteruskan. Nilai fungsi aktivasi (keluaran model jaringan) juga 
dapat dipakai sebagai dasar untuk mengubah bobot perhitungan Input ANN.

\subsection{Algoritma Genetika}

Metode Algoritma Genetika (AG) adalah suatu algoritma pencarian yang berbasis pada mekanisme seleksi alam dan genetika. Algoritma genetika merupakan salah satu algoritma yang sangat tepat digunakan dalam menyelesaikan masalah optimasi kompleks, yang sulit dilakukan oleh metode konvensional. Algoritma genetika diperkenalkan pertama kali oleh John Holland (1975) dari Universitas Michigan.

John Holland menyatakan bahwa setiap masalah yang berbentuk adaptasi (alami maupun buatan) dapat diformulasikan ke dalam terminologi genetika. Sifat algoritma genetika adalah mencari kemungkinan dari calon solusi untuk mendapatkan solusi yang optimal dalam penyelesaian masalah. Ruang cakupan dari semua solusi yang layak, yaitu berbagai obyek diantara solusi yang sesuai, yang dinamakan ruang pencarian. Tiap titik didalam ruang pencarian mempresentasikan satu solusi yang layak. Tiap solusi yang layak dapat ditandai dengan nilai fitnessnya. Solusi yang dicari dalam algoritma genetika adalah titik (satu atau lebih) diantara solusi yang layak dalam ruang pencarian. Sifat pencarian inilah yang menyebabkan algoritma genetika baik untuk diterapkan dalam menyelesaikan masalah $N P$ complete.

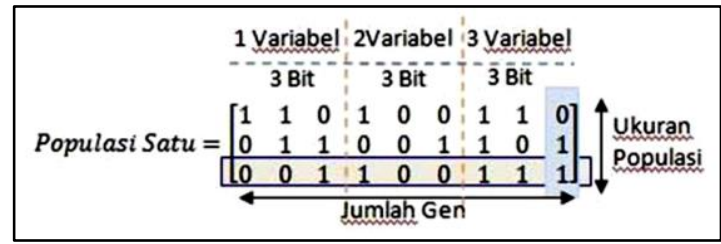

\section{Gambar 4 - Proses Populasi Ukuran Algoritma Genetika}

Inisialisasi populasi merupakan langkah awal dalam penyelesaian AG. Dalam prosesnya populasi dilambangkan sebagai sebuah deretan bilangan biner 0 dan 1, yang tersusun atas kolom dan baris sehingga membentuk suatu matriks berisi bilangan biner. Pada satu deret baris matriks tersusun atas beberapa kolom. Satu deret baris matriks ini pada AG dikenal dengan istilah kromosom sedangkan jumlah kolom tersebut dikenal dengan istilah jumlah gen. Nilai jumlah gen tersebut merupakan perkalian nilai Nvar (jumlah variabel) dan nilai Nbit (jumlah bit). Nvar merupakan jumlah variabel yang mewakili dari sebuah kromosom dan Nbit yaitu jumlah bit biner yang mewakili sebuah variabel. Sedangkan jumlah baris pada sebuah matriks tersebut dikenal dengan istilah UkPop (Ukuran Populasi). Untuk lebih jelasnya dapat dilihat pada Gambar 4.

\section{Hasil dan Pembahasan}

\subsection{Analisis Hasil Regresi Linear Berganda}

Langkah awal sebelum melakukan peramalan regresi linier berganda adalah dengan melakukan validasi model peramalan. Validasi peramalan dilakukan dengan menghitung tingkat galat atau error peramalan selama periode Januari 2017 - Agustus 2019. Perhitungan error yang digunakan adalah Mean Absolut Percentage Error (MAPE), Mean Squared Error (MSE), dan Root Mean Square Error (RMSE). Hasil error dari metode regresi linier berganda akan dibandingkan dengan metode lainnya.

Tabel 3 - Hasil Error Peramalan Metode Regresi Linier Berganda

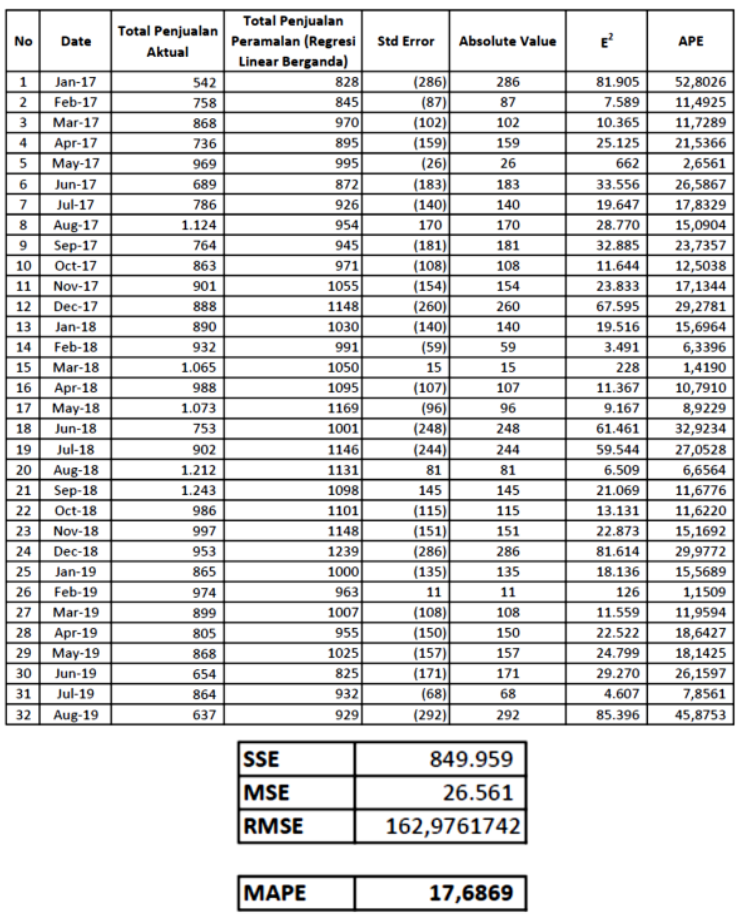

Berdasarkan Tabel 3, peramalan dengan menggunakan metode regresi linier berganda memiliki nilai MAPE sebesar 17,6869 \%, MSE sebesar 26.561, dan RMSE sebesar 849.959. Kemampuan peramalan dikatakan sangat baik apabila nilai MAPE kurang dari 10\%, serta dikatakan baik apabila nilai MAPE kurang dari 20\% (Makridarkis, et al, 1999). Maka dari itu penulis selanjutnya akan membahas bagaimana variabel yang berhubungan dengan penjualan $\mathrm{B} 2 \mathrm{~B}$ dalam dunia otomotif 
memiliki dampak signifikan pada peramalan penjualan kendaraan mobil segmen B2B apabila dikombinasikan dengan variabel penjualan kendaraan mobil secara umum.

\subsection{Analisis Hasil Jaringan Saraf Tiruan}

Dalam melakukan analisis jaringan saraf tiruan dibantu dengan penggunaan software MATLAB R2015a. Analisis jaringan saraf tiruan dilakukan dengan mengunakan semua faktor sebagai input data. Hasil analisis peramalan yang dilakukan ditunjukan pada Tabel 4.

Tabel 4 - Hasil Error Peramalan Jaringan Saraf Tiruan

\begin{tabular}{|c|c|c|c|c|c|c|c|}
\hline No & DATE & $\begin{array}{c}\text { Total Penjualan } \\
\text { Aktual }\end{array}$ & $\begin{array}{l}\text { Total Penjualan } \\
\text { Peramalan (IST) }\end{array}$ & Std Error & Absolute Value & $E^{2}$ & APE \\
\hline 1 & Jan-17 & 542 & 589 & (47) & 47 & 2.209 & 8,6716 \\
\hline 2 & Feb-17 & 758 & 838 & (80) & 80 & 6.400 & 10,5541 \\
\hline 3 & Mar-17 & 868 & 1079 & (211) & 211 & 44.521 & 24,3088 \\
\hline 4 & Ap -17 & 736 & 874 & (138) & 138 & 19.044 & 18,7500 \\
\hline 5 & Mer-17 & 969 & 1035 & $\mid(66)$ & 66 & 4.356 & 6,8111 \\
\hline 6 & Jun-17 & 689 & 691 & (2) & 2 & 4 & 0,2903 \\
\hline 7 & Jul-17 & 786 & 880 & (94)| & 94 & 8.836 & 11,9593 \\
\hline 8 & Agt-17 & 1.124 & 1168 & (44) & 44 & 1.936 & 3,9146 \\
\hline 9 & Sep-17 & 764 & 919 & (155) & 155 & 24,025 & 20,2880 \\
\hline 10 & 0kt:17 & 863 & 1019 & (156) & 156 & 24,336 & 18,0765 \\
\hline 11 & Nov-17 & 901 & 953 & (52) & 52 & 2.704 & 5,7714 \\
\hline 12 & Des 17 & 888 & 938 & (50) & 50 & 2.500 & 5,6306 \\
\hline 13 & Jan-18 & 890 & 962 & (72) & 72 & 5.184 & 8,0899 \\
\hline 14 & Feb-18 & 932 & 97 & (45) & 45 & 2.025 & 4,8283 \\
\hline 15 & Mar -18 & 1.065 & 1097 & (32) & 32 & 1.024 & 3,0047 \\
\hline 16 & Apr-18 & 988 & 1028 & (40) & 40 & 1.600 & 4,0486 \\
\hline 17 & Mei-18 & 1.073 & 1075 & (2) & 2 & 4 & 0,1864 \\
\hline 18 & Jun-18 & 753 & 785 & (32) & 32 & 1.024 & 4,2497 \\
\hline 19 & Jul-18 & 902 & 889 & 13 & 13 & 169 & 1,4412 \\
\hline 20 & Agt-18 & 1.212 & 1111 & 101 & 101 & 10.201 & 8,3333 \\
\hline & & & SSE & \multicolumn{2}{|c|}{162.102} & & \\
\hline & & & MSE & \multicolumn{2}{|c|}{8.105} & & \\
\hline & & & RMSE & \multicolumn{2}{|c|}{90,02832887} & & \\
\hline & & & MAPE & \multicolumn{2}{|c|}{8,4604} & & \\
\hline
\end{tabular}

Pada Tabel 4 diketahui bahwa tingkat galat atau error dari hasil peramalan dengan JST/ANN memiliki nilai MAPE sebesar 8,4604\%, MSE sebesar 8.105, dan RMSE 90,0283. Nilai error ini relatif lebih kecil dibandingkan hasil metode sebelumnya yaitu Regresi Linear Berganda.

\subsection{Analisis Hasil Jaringan Saraf Tiruan - Algoritma Genetika}

Langkah-langkah peramalan dengan menggunakan metode jaringan saraf tiruan (JST) atau artificial neural network (ANN) yang dioptimasikan bobot dan bias dengan Alogritma Genetik menggunakan bantuan software MATLAB R2015a. Secara umum sistem yang dibangun terbagi menjadi dua proses, yaitu pelatihan (training) dan pengujian (testing). Proses pelatihan mengunakan algoritma genetika untuk mendapatkan komposisi bobot yang optimal pada JST dengan mengkodekan bobot dan bias dalam kromosom. Penentuan kromosom (konfigurasi bobot dan bias) yang baik didasarkan atas nilai fitness yang dihitung dengan melakukan proses feedforward menggunakan nilai dari kromosom tersebut. Nilai fitness merupakan tingkat error atau selisih dari hasil peramalan dengan nilai sebenarnya. Proses pelatihan JST menggunakan AG dilakukan dengan mengkodekan bobot dan bias JST ke dalam kromosom dengan reprsentasi real. Inti dari teori JST adalah bagaimana menemukan bobot dan bias yang tepat. Algoritma Genetika akan mengatur bobot dan bias untuk mencapai titik optimum. Hasil analisis peramalan yang dilakukan ditunjukan pada di bawah :

Tabel 5 - Hasil Error Peramalan Jaringan Saraf Tiruan - Algoritma Genetika

\begin{tabular}{|c|c|c|c|c|c|c|c|}
\hline No & DATE & $\begin{array}{c}\text { Total Penjualan } \\
\text { Aktual }\end{array}$ & $\begin{array}{c}\text { Total Penjualan } \\
\text { Peramalan (IST-AG) }\end{array}$ & Std Error & Absolute Value & $\mathrm{E}^{2}$ & APE \\
\hline 1 & $\operatorname{Jan}-17$ & 542 & 588 & (46) & 46 & 2.116 & 8,4871 \\
\hline 2 & Feb-17 & 758 & 722 & 36 & 36 & 1.296 & 4,7493 \\
\hline 3 & Mar -17 & 868 & 1052 & (184) & 184 & 33.856 & 21,1982 \\
\hline 4 & Apr 17 & 736 & 727 & 9 & 9 & 81 & 1,2228 \\
\hline 5 & Met-17 & 969 & 970 & (1) & 1 & 1 & 0,1032 \\
\hline 6 & Jun-17 & 689 & 604 & 85 & 85 & 7.225 & 12,3367 \\
\hline 7 & $J u \mid \cdot 17$ & 786 & 793 & (7) & 7 & 49 & 0,8906 \\
\hline 8 & Agt:-17 & 1.124 & 1124 &. & 0 & $\cdot$ & 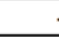 \\
\hline 9 & Sep-17 & 764 & 778 & (14) & 14 & 196 & 1,8325 \\
\hline 10 & Okt:17 & 863 & 840 & 23 & 23 & 529 & 2,6651 \\
\hline 11 & Nov-17 & 901 & 919 & (18) & 18 & 324 & 1,9978 \\
\hline 12 & Des- 17 & 888 & 864 & 24 & 24 & 576 & 2,7027 \\
\hline 13 & Jan-18 & 890 & 1092 & (202) & 202 & 40.804 & 22,6960 \\
\hline 14 & Feb-18 & 932 & 1113 & (181) & 181 & 32.761 & 19,4206 \\
\hline 15 & Mar -18 & 1.065 & 1080 & (15) & 15 & 225 & 1,4085 \\
\hline 16 & Apr 18 & 988 & 1000 & (12) & 12 & 144 & 1,2146 \\
\hline 17 & Met-18 & 1.073 & 1070 & 3 & 3 & 9 & 0,2796 \\
\hline 18 & Jun-18 & 753 & 818 & (65) & 65 & 4.225 & 8,6321 \\
\hline 19 & Jul-18 & 902 & 987 & (85) & 85 & 7.225 & 9,4235 \\
\hline 20 & Agt:18 & 1.212 & 1183 & 29 & 29 & 841 & 2,3927 \\
\hline & & & SSE & \multicolumn{2}{|c|}{132.483} & & \\
\hline & & & MSE & \multicolumn{2}{|c|}{6.624} & & \\
\hline & & & RMSE & \multicolumn{2}{|c|}{81,3888813} & & \\
\hline
\end{tabular}

\begin{tabular}{|l|r|}
\hline MAPE & 6,1827 \\
\hline
\end{tabular}

Pada Tabel 5 diketahui bahwa tingkat galat atau error dari hasil peramalan dengan JST dengan optimasi GA memiliki nilai MAPE sebesar 6,1827\%, 
MSE sebesar 6.624, dan RMSE 81,3888. Nilai error ini relatif lebih kecil dibandingkan hasil dua metode sebelumnya yaitu Regresi Linear Berganda dan Jaringan Saraf Tiruan.

\section{Kesimpulan dan Saran}

Terdapat beberapa kesimpulan yang diperoleh dari penelitian peramalan produk insektisida yang telah dilakukan.

1. Berdasarkan perbandingan nilai error hasil peramalan regresi linier berganda didapatkan MAPE sebesar $17,68 \%$ dan apabila dibandingkan dengan teori masih dalam kategori baik apabila diantara $10 \%$ - 20\%. Namun penulis merasa perlu mendapatkan variabel penjualan segmen B2B untuk dianalisa kemudian menggunakan teknik kuesioner dan scoring yang diujikan pada Jaringan Saraf Tiruan.

2. Berdasarkan perbandingan tingkat error pada ketiga metode yang digunakan pada penelitian ini, metode jaringan saraf tiruan dengan optimasi menggunakan Algoritma Genetika merupakan metode yang paling baik dengan nilai MAPE sebesar $6,18 \%$, dimana nilai MAPE metode Jaringan Saraf Tiruan Biasa sebesar 8,46\%. Analisa mengguanakan Jaringan Saraf Tiruan yang dioptimasi dengan Algoritma Genetika mampu mengurangi tingkat error pada peramalan khususnya untuk segmen $\mathrm{B} 2 \mathrm{~B}$ penjualan kendaraan mobil.

Adapun saran kedepannya untuk penelitian mengenai segmen B2B yaitu persiapan pada pengaruh tuntutan masa depan dan industri 4.0 dengan menyisipkan dampak pergeseran jenis kendaraan dari berbahan bakar fosil menjadi berbahan bakar listrik (Electrical Vehicle).

\section{DAFTAR PUSTAKA}

Brax, S. A., and Visintin, F. (2017). Meta-Model of Servitization: The Itegrative Profiling Approach. Industrial Marketing Management, 60, pp. 17-32.

Caruana, A. (2001). Steps in Forecasting with Seasonal Regression: A Case Study from the Carbonated Soft Drink Market. Journal of Product \& Brand Management, 10, pp. 94102.

Chouksey, P., Deshpande, A., Agarwal, P., Gupta , D. R. (2018). Sales Forecasting Study in An Automobile Company: A Case Study. Industrial Engineering Journal, 10(12).

Cristiana, M. (2009). The Buying Decision Process and Types of Buying Decision Behaviour.
Sibiu Alma Mater University Journals. Series A. Economic Sciences, 2(4).

Draper, N. R. and Smith H. (1992) Applied Regression Analysis. Canada: John Wiley \& Sons.

Gao, J., Xie, Y., Cui, X., Yu, H., and Gu, F. (2018). Chinese Automobile Sales Forecasting using Economic Indicators and Typical Domestic Brand Automobile Sales Data: A Method Based on Econometric Model. Advances in Mechanical Engineering, 10(2), pp. 1-11.

Jennie, B., Elina, L., \& Linda-Marie, W. (2005 ). What Influences B2B Buying Behaviour?: An Empirical Study of Fläkt Woods and Its Customers. Bachelor's Thesis in Marketing.

Keller, K. L. (1993). Conceptualizing, Measuring, and Managing Customer Based Brand Equity. Journal of Marketing, 12(1).

Keshvari, R.S. (2012). The Impact of B2B Buying Behavior on Customer Satisfaction within SHAHAB KHODRO Company. International Journal of Business and Management, 7(7).

Lihua, Y. and Baolin, L. (2016), The Combination Forecasting Model of Auto Sales Based on Seasonal Index and RBF Neural Network. International Journal of Database Theory and Application, 9(1), pp.67-76.

Makridarkis, S., Wheelwright, S. C., and McGee, V. E (Terjemahan). (1999). Metode dan Aplikasi Peramalan Edisi 2. Jakarta : Binarupa Aksara

Ravi, P., Quester, P.G., and Cooksey, R. W. (2006). Consumer-Based Brand Equity and Countryof-Origin Relationships: Some Empirical Evidence. European Journal of Marketing, 40(5/6). 